\title{
The Nexus: Estimation of Water Consumption for Hydropower in Brazil
}

\author{
Theodoros Semertzidis ${ }^{*}$, Catalina Spataru ${ }^{2}$, Raimund Bleischwitz ${ }^{3}$ \\ ${ }^{1}$ Institute for Sustainable Resources, University College London, 14 Upper Woburn Place, WC1H 0NN, \\ London, United Kingdom \\ e-mail: t.semertzidis@ucl.ac.uk \\ ${ }^{2}$ Energy Institute, University College London, 14 Upper Woburn Place, WC1H 0NN, London, \\ United Kingdom \\ e-mail: c.spataru@ucl.ac.uk \\ ${ }^{3}$ Institute for Sustainable Resources, University College London, 14 Upper Woburn Place, WC1H 0NN, \\ London, United Kingdom \\ e-mail: r.bleischwitz@ucl.ac.uk
}

Cite as: Semertzidis, T., Spataru, C., Bleischwitz, R., The Nexus: Estimation of Water Consumption for Hydropower in Brazil, J. sustain. dev. energy water environ. syst., 7(1), pp 122-138, 2019, DOI: https://doi.org/10.13044/j.sdewes.d6.0229

\begin{abstract}
Recent major droughts in Brazil have given rise to discussions about water availability and security in relation to energy production. The relationship of the two resources, the water-energy nexus, is recognised as being of importance in literature and metrics for its estimation and understanding are sought after. One important aspect in understanding the water-energy nexus of hydroelectricity is estimating its water consumption and also its water footprint. In order to do this, this study uses a modified Penman-Monteith method to estimate evaporation from Brazil's reservoirs for the period 2010-2016 and subsequently calculates the water footprint of hydroelectricity reservoirs. The results show the evaporation variation in space and time in the reservoirs and the differences of water consumed per unit of energy in Brazil. The discussion provides insight as to how the results can be valuable for future management and planning purposes.
\end{abstract}

\section{KEYWORDS}

Hydropower, Water-energy nexus, Water consumption, Evaporation, Water footprint.

\section{INTRODUCTION}

Firstly, the issues Brazil has recently faced due to droughts are explored, together with the recognition of the scientific community on the burden of electricity generation on water resources. The current knowledge and research gaps of hydroelectricity are then identified, finally followed by a focus on the water consumption of electricity generation, narrowing down to hydroelectricity.

\section{Brazil and hydroelectricity}

A major drought hit the Southeast of Brazil in 2014 affecting millions of people in the Sao Paulo, Rio de Janeiro and Minas Gerais states. The prolonged drought caused severe

* Corresponding author 
water shortages, with reservoirs falling below $5 \%$ of their capacity. These states are home to the largest cities in Brazil and the drought put the states in competition over access to the shared Rio Jaguari river basin. Furthermore, this also caused trade-offs between different water uses (e.g., hydro power generation, wastewater treatment, urban supply). The dispute almost reached Brazil's Supreme Court, before the National Water Agency intervened and mediated an agreement between states [1]. This "water-war" revealed deficiencies in water governance and infrastructure, which led back to the importance of research on basic water resources management, and the need for better planning to help towards the prevention of similar future situations. The 2014 drought was the last of a series of droughts affecting the country in the last decade. For example, another major one affected the Northeast in 2010. Furthermore, Brazil plans to meet growing electricity demand with new hydropower plants with a total capacity of 29 GW from 2014 to 2024 , mainly located in the Amazon basin, which accounts for $41 \%$ of the overall expansion planned [2]. These new tropical forest plants might even cause significant greenhouse gas emissions [3], among other effects like inundation of agricultural land, loss of vegetation and fauna, and relocation of populations.

The burden of electricity generation on water resources has been recognized internationally, often in the context of the water-energy nexus, and it has been discussed in various publications. Examples of such work include Cooley et al. [4] where water for energy in the intermountain West of the USA is investigated, the seminal excerpt "Water for Energy" from the World Energy Outlook 2012 by the International Energy Agency [5], and also the World Bank's "Thirsty Energy" by Rodriguez et al. [6] which tackles the water demands of power generation and management of the Nexus. It was not until 2012 and the "Special Report on Renewable Energy Sources and Climate Change Mitigation" by the Intergovernmental Panel on Climate Change (IPCC) [7] that the impact of hydroelectricity on water resources started receiving more attention. This was due to the wide range of estimates on water consumption per unit of energy generated by hydropower plants, but also because some of these values were much higher than power sources like thermal, nuclear and biomass, as shown in Table 1.

Table 1. Water consumption values of different fuels [8]

\begin{tabular}{cc}
\hline Fuels & Median water consumption $\left[\mathrm{m}^{3} / \mathrm{MWh}\right]$ \\
\hline Biopower tower steam & 2.1 \\
Nuclear tower & 2.54 \\
Natural gas tower combined cycle & 0.78 \\
Natural gas tower steam & 3.13 \\
Coal tower generic & 2.6 \\
Hydro & 17 \\
\hline
\end{tabular}

Despite IPCC's and others' reports, water use from dams for energy generation has traditionally been considered a non-consumptive use in Brazil [9]. Although the Brazilian Electric System National Operator (ONS) did a report on evaporative losses from hydroelectric reservoirs in 2004 [10], these are not considered in water resources planning and management on a river basin level, nor has any extensive research been done since then [11]. In recent years, due to the multiple drought events, the debate has started to slowly resurface as becomes clear from Bueno et al. [11] in their work on evaporation and water footprint for the Camargos hydropower plant reservoir, and also Fischmann and Chaffe's [12] work on the water footprint of hydroelectricity in Santa Catarina State, Brazil.

\section{Current knowledge and research gaps}

It is a challenge for governments to embrace the multiple aspects, roles and benefits of water, and to place water at the heart of decision-making in all sectors that depend on 
it. Water resources and the improvement of water-related services have historically been more of a public health and welfare issue, also being considered as a public good, with access to fresh water and sanitation falling into the human rights category. Neither of these concepts applies to energy, which is reflected in economic, social and political aspects [13]. Due to these and other reasons, there is a lack of data on water resources management, which puts water at a political disadvantage in terms of priority decision-making. To prevent future unwanted situations, more work is needed on water resources, and a clear linkage needs to be made with other water demanding sectors.

One important aspect of lack of water resources management work is in water consumption caused by hydroelectricity generation, which may exacerbate regional water scarcity problems as is argued by Fthenakis and Kim [14] in their paper on life-cycle uses of water in U.S. electricity generation, and also by Gerbens-Leenes et al. [15] in their paper on the water footprint of energy from biomass. This gap was first recognized by Gleick [16] in his highly influential work "Water and Energy". Consequently, it becomes a matter of great importance to accurately assess the water consumption of hydroelectric power. The uncertainty in the water consumption from hydroelectricity is very high though. It was estimated by Torcellini et al. [17] to range from 0 to 18,000 gallons per MWh $\left(68.14 \mathrm{~m}^{3} / \mathrm{MWh}\right)$. This uncertainty is an indication of the difficulty to estimate water use factors for different electric power generation types and studies that extrapolate the aggregate water demands for energy scenarios based on those factors. The two main issues include the estimation of evaporative losses at reservoirs, and allocations of those losses to power generation relative to the various uses of the reservoir (e.g., agriculture, municipal uses, etc.) [18].

Many reservoirs have multiple uses (e.g., agricultural, industrial, domestic) in addition to generation of hydroelectricity [19], so water losses cannot always be attributed to power generation purposes alone [20]. There is no commonly accepted methodology for determining how much reservoir evaporation should be attributed to hydroelectricity or other uses as is recognized in the seminal paper on consumptive water use of the U.S. power production by Torcellini et al. [17], but also by Bakken et al. [21] in their review of published estimates of water consumption from hydropower plants. This issue was once again recognized by Gleick [22] a decade earlier, in 1992, in his paper on environmental consequences of hydroelectric development. Although reservoirs usually have different uses, the vast majority of reservoirs in Brazil that are used for hydroelectricity are solely used for that purpose, which is recognized by Lehner et al. [23] in their "high-resolution mapping of the world's reservoirs and dams for sustainable river-flow management" paper, and clearly seen in AQUASTAT's geo-referenced database on dams [24]. Therefore, for the purpose of this paper, all evaporative losses are attributed to hydroelectricity production. There has been some work done by Pasqualetti and Kelley [25] and Zhao and Liu [26] that proposed allocating evaporative water losses to the various uses of the reservoir on the economic value of those different uses, but this possible solution needs additional research done.

Evaporation is the most obvious consumptive use of water, but its estimation is difficult. Evaporation is part of the normal hydrological cycle, however, since these large reservoir areas would not exist if it were not for the dams built there, evaporation stemming from there is considered to be a consumptive use and it is attributed to the hydroelectric plants. To avoid confusion, it is important to make a clear distinction between important terms. According to the Food and Agriculture Organization of the United Nations (FAO), evaporation is: "The process whereby liquid water is converted to water vapour and removed from the evaporating surface”. Evaporating surfaces include lakes, rivers, pavements, soils, and wet vegetation. On the other hand, transpiration "Consists of the vaporization of liquid water contained in plant tissues and the vapour removal to the atmosphere". Crops lose most of the water that they consume through their stomata (small openings on the plant's leafs). 
Recent studies by Maestre-Valero et al. [27] and Martinez-Granados et al. [28] on economic impacts of evaporative losses in the Segura Basin in Spain, but also by Gallego-Elvira et al. [29] on their work on the "Impact of micrometeorological conditions on the efficiency of artificial monolayers in reducing evaporation", show that a large amount of water is lost due to evaporation from lakes and reservoirs leading to huge waste of resources. There are major hydrologic and economic impacts because of this, and evaporation losses for water management should be taken into account in future projections. Estimating evaporation from lakes and reservoirs though is not a simple task because of the many factors affecting evaporation rate, especially the climate and physiography of the water body and its surroundings [30].

\section{The water consumption of electricity generation gap}

There have been articles in recent years providing consolidated estimates of water withdrawal and consumption for the full life cycle of selected electricity generating technologies, with water used for cooling of thermoelectric power plants dominating these publications. These estimates are gathered through a broad search of publicly available sources of data. The two most common sources are the United States Geological Survey (USGS) [31] and the Energy Information Administration (EIA) [32]. Past work includes Gleick [16], Fthenakis and Kim [14], Mielke et al. [33], Cooley et al. [4], Averyt et al. [34], Macknick et al. [8] and Meldrum et al. [35], which all address water use across varying degrees of the life cycle. It is important to notice that most of these publications follow the USGS's [36] classification of water use, into water withdrawals referring to "water removed from the ground or diverted from a surface-water source for use' ( $p$ 49), and water consumption referring to the portion of withdrawn water not returned to the 'immediate water environment' ( $p$ 47).

Despite extensive collection, screening and harmonization efforts of these publications, the gathered estimates for most generation technologies and life cycle stages remain few in number and wide in range as is evident by both Averyt's et al. [34] work on freshwater use by U.S. power plants, and Meldrum's et al. [35] paper on the life cycle water use for electricity generation. Nevertheless, these estimates are still used very widely in energy and water modelling.

An important problem is that the estimates of water consumption and withdrawal are displayed irrespective of geographic location, but the location of a plant and the corresponding climatic conditions may affect the overall efficiency and water use rate. This important realization was acknowledged by Dziegielewski and Bik [37] in their work on water use in thermoelectric power plants, Yang and Dziegielewski [38] on the continuous work on water use of thermoelectric power plants in the U.S., and Rutberg et al. [39] on similar research on the presentation of a model of water use at power plants. Even more specific to hydroelectricity, reservoir evaporation, which is considered a complicated issue, is in all these publications based on Gleick's work [16] and the paper from Torcellini et al. [17], which gave estimates ranging from 0 to $68.14 \mathrm{~m}^{3} / \mathrm{MWh}$. Macknick et al. [8], again based on the same two papers, gave a minimum of 5.4, a maximum of 68.14 , and a median value of $17 \mathrm{~m}^{3} / \mathrm{MWh}$.

Regardless of the norm in data used in energy and water modelling, there have been studies that compare and assess evapotranspiration methods for land surfaces or estimating required parameters in limited data conditions around the world, and also Brazil. Examples include work done by Carvalho et al. [40] using the Penman-Monteith equation for missing data, Mendonca et al. [41] estimating evapotranspiration in North Fluminense in Rio de Janeiro, Brazil, and da Cunha et al. [42] estimating evapotranspiration in Paranaiba city, Brazil. At the same time, studies that estimate lake or reservoir evaporation in the conditions that long term data required are not available are a rare occurrence, and therefore there is no clear consensus as to which methodology 
is the best one when there is a lack of important long-term measured data like temperature profiles, radiation and heat fluxes [43].

ONS published a study in 2004 that estimated average monthly evaporation values for all major Brazilian hydropower plants, based on average climate data for several locations for the years 1931 to 1990 [10]. To our knowledge, this has been the only such study that has taken place considering all hydropower reservoirs in the country.

In 2016, Fischmann and Chaffe [12] published a study that estimated the water footprint of hydroelectricity in Santa Catarina State in Southern Brazil. They incorporated algorithms proposed by Morton [44] in order to avoid a large amount of required input data and to have the possibility to apply the method to varying contexts without the need for locally optimized coefficients. They used time series data of weather parameters retrieved from the website of the Brazilian National Institute of Meteorology (INMET) [45]. The scope of this study was constrained by the lack of data availability regarding reservoir properties and electricity generation, especially that of smaller facilities [12]. Also in 2016, Bueno et al. [11] published a study that used the water footprint definition by Mekonnen and Hoekstra [46] and calculated the monthly water footprint of the Camargos reservoir. They calculated evaporation for the period between 2010 and 2014 using four methods: Linacre, Penman, Penman-Monteith and the ONS method. The results indicated an average $1,329 \mathrm{~mm} /$ year evaporation and showed that in 2014 the evaporation values were higher due to the severe dry season that affected the region. This also shows the importance of calculating evaporation from hydroelectric reservoirs [11]. Finally, Mekonnen and Hoekstra [46] estimated the water footprint of electricity from hydropower for 35 power stations around the world, including 8 from Brazil. They used the modified Penman-Monteith equation for the estimation of evaporation that is also used in the present study.

This study will add to the current research by providing estimates of water evaporation and water footprint from hydropower reservoirs/plants in Brazil for the period 2010-2016.

\section{METHODS}

The methodology consists of the following steps:

- Finding the nearest meteorological stations to the reservoirs;

- Calculating the evaporation for each reservoir;

- Calculating the water footprint of the hydropower plants.

\section{Spatial analysis of meteorological stations' locations}

To find the nearest meteorological stations to the reservoirs, the spherical law of cosines was used, which is described by the following equation:

$$
d=\operatorname{acos}\left(\sin \varphi_{1} \times \sin \varphi_{2}+\cos \varphi_{1} \times \cos \varphi_{2} \times \cos \Delta \lambda\right) \times R
$$

where $\varphi$ is latitude, $\lambda$ is longitude and $R$ is the earth's radius (mean radius $=6,371 \mathrm{~km}$ ).

Through a data cleaning process, we ended up with the weather stations that provided accurate data for each reservoir starting from the $1^{\text {st }}$ of January 2010 . We also carried out a check on altitudes of the reservoirs and the weather stations in order for them to not have a significant difference. Distances between the reservoirs and the weather stations vary from a minimum of $3 \mathrm{~km}$ to a maximum of $223 \mathrm{~km}$. Only 8 reservoirs were further than $100 \mathrm{~km}$ (7 between 101 and $161 \mathrm{~km}$ and 1 which was $223 \mathrm{~km}$ ) from a weather station. The average distance of the rest was about $40 \mathrm{~km}$. Though these few large distances are significant, the climate in these areas (the Amazon region) does not vary significantly, therefore making the assumption logical. 


\section{Calculation of evaporation}

The rate of evaporation is calculated, which is mainly controlled by the available energy and the ease with which water vapour diffuses into the atmosphere. The available energy refers to the combination of the net radiation at the lake's surface and the amount of heat stored in the water [30]. Generally, the rate of evaporation from any wet surface is determined by three factors: the physical state of the surrounding air, the net available heat, and the wetness of the evaporating surface [47]. More specifically, evaporation rate is the difference between the vaporization rate (function of temperature) and the condensation rate (function of vapour pressure) [48]. In the case of deep lakes and reservoirs, like in Brazil, heat storage of the water body affects the surface energy flux and needs to be taken into account. Similarly, the effects of salinity, which reduces evaporation, and water advected energy, need to be addressed as well, if applicable [49].

Several evaporation methods were comprehensively reviewed by de Bruin and Stricker [50], Lenters et al. [51], Rosenberry et al. [52], Stephen et al. [53], Shakir et al. [54], and McJannet et al. [55]. There have been many studies for comparing and assessing evapotranspiration methods for land surfaces, but the same does not hold true for methods for estimating lake evaporation in the conditions that long term data required are not available. Therefore, there is no consensus as to which methods are the best ones to use [43]. There are various methods for estimating open water evaporation, but generally they can be categorized into a few major types: pan evaporation, mass balance, energy budget, bulk transfer, and combination methods [30]. Each of them has advantages and disadvantages, and there are studies that review them in detail like Gallego-Elvira et al. [29], Stephen et al. [53], Shakir et al. [54], and McJannet et al. [55].

Combination methods integrate bulk transfer and energy budget in a single equation. The most commonly used (also suggested by FAO) is the Penman-Monteithone [56]. This requires inputs of net radiation, air temperature, vapour pressure, and wind speed. The Penman-Monteith approach allows adjustment to the amount of energy available for evaporation based on changes in heat storage within the water body. The loss of heat through evaporation is an important part of the energy calculation used to calculate temperature [57]. McMahon et al. [49] conclude that the Penman-Monteith model that incorporates a seasonal heat storage component and a water advection component, and the Morton CRLE model are the most suitable ones to estimate evaporation from deep lakes and large voids. Since the Penman-Monteith method has not been used to estimate evaporation for the whole country before (unlike the Morton method, which ONS used in 2004), and since it is the method suggested by FAO, it was deemed suitable to use the Penman-Monteith equation [eq. (2)], adjusted by McJannet et al. [57] to account for deep lakes:

$$
E=\frac{1}{\lambda}\left[\frac{\Delta_{\mathrm{w}}(Q-N)+86,400 \rho_{\mathrm{a}} C_{\mathrm{a}} \frac{\left(e_{\mathrm{w}}-e_{\mathrm{a}}\right)}{r_{\mathrm{a}}}}{\Delta_{\mathrm{w}}+\gamma}\right]
$$

where $E$ is evaporation [mm/d], $\lambda$ is latent heat of vaporization $[\mathrm{MJ} / \mathrm{kg}], \Delta_{\mathrm{w}}$ is the slope of the temperature saturation water vapour curve at water temperature $\left[\mathrm{kPa} /{ }^{\circ} \mathrm{C}\right], Q$ is net radiation $\left[\mathrm{MJ} / \mathrm{m}^{2} \mathrm{~d}\right], N$ is change in heat storage in the water body $\left[\mathrm{MJ} / \mathrm{m}^{2} \mathrm{~d}\right], \rho_{\mathrm{a}}$ is density of air $\left(1.2 \mathrm{~kg} / \mathrm{m}^{3}\right), C_{\mathrm{a}}$ is specific heat of air $\left(0.001013 \mathrm{MJ} / \mathrm{kg}{ }^{\circ} \mathrm{K}\right), e_{\mathrm{w}}$ is saturation vapour pressure at water temperature $[\mathrm{kPa}], e_{\mathrm{a}}$ is daily vapour pressure (taken at 9:00 AM) $[\mathrm{kPa}]$, $r_{\mathrm{a}}$ is aerodynamic resistance $[\mathrm{s} / \mathrm{m}]$, and $\gamma$ is psychometric constant $\left[\mathrm{kPa} /{ }^{\circ} \mathrm{C}\right]$.

Using the adjusted Penman-Monteith equation requires hourly data, which were not collected in Brazil since relatively recently (about 2006). To the best of our knowledge, there is no nationwide network for monitoring reservoir evaporation in Brazil, so it is 
important to have actual values of the aforementioned inputs for this equation (net radiation, air temperature, vapour pressure, and wind speed). It is recommended that evaporation estimates are based on data from a nearby weather station that is considered to have a similar climate to the site in question [49]. In recent years with the introduction of a number of new weather stations, it has become feasible to have a good proximity of weather stations and reservoirs, making in turn calculations feasible and more reliable.

Eq. (2) needs eight different inputs, which are separated into site characteristics and time series inputs. Table 2 presents these inputs and the source for the data required.

Table 2. Inputs for the modified Penman-Monteith equation for calculation of evaporation

\begin{tabular}{|c|c|c|c|}
\hline \multicolumn{2}{|c|}{ Site characteristics } & \multicolumn{2}{|c|}{ Time series } \\
\hline Input & Source & Input & Source \\
\hline$A=$ water body area $\left[\mathrm{km}^{2}\right]$ & $\begin{array}{l}\text { The Brazilian Electricity } \\
\text { Regulatory Agency } \\
\text { (ANEEL) and power } \\
\text { station websites }\end{array}$ & $\begin{array}{c}T_{\mathrm{a}}=\text { mean daily air } \\
\text { temperature }\left[{ }^{\circ} \mathrm{C}\right]\end{array}$ & $\begin{array}{l}\text { Provided by INMET } \\
\text { after personal } \\
\text { communication }\end{array}$ \\
\hline$Z=$ water depth $[\mathrm{m}]$ & $\begin{array}{l}\text { Calculated using } \\
\text { reservoir capacity data } \\
\text { from ONS and } \\
\text { AQUASTAT }\end{array}$ & $\begin{array}{c}E_{\mathrm{a}}=\text { daily vapour } \\
\text { pressure (taken at } \\
\text { 9:00 AM) }[\mathrm{kPa}]\end{array}$ & $\begin{array}{l}\text { Calculated by knowing } \\
\text { the air temperature at } \\
\text { 09:00 AM of each day }\end{array}$ \\
\hline$\psi=$ water body altitude $[\mathrm{m}]$ & $\begin{array}{l}\text { Google Earth Pro and } \\
\text { power station websites }\end{array}$ & $\begin{array}{c}K \Downarrow=\text { total daily } \\
\text { incoming short-wave } \\
\text { radiation }\left[\mathrm{MJ} / \mathrm{m}^{2} \mathrm{~d}\right]\end{array}$ & $\begin{array}{l}\text { Provided by INMET } \\
\text { after personal } \\
\text { communication }\end{array}$ \\
\hline$\varphi=$ latitude [radians] & $\begin{array}{l}\text { Google Earth Pro and } \\
\text { power station websites }\end{array}$ & $\begin{array}{c}U_{10}=\text { average daily } \\
\text { wind speed at } 10 \mathrm{~m} \\
{[\mathrm{~m} / \mathrm{s}]}\end{array}$ & $\begin{array}{l}\text { Provided by INMET } \\
\text { after personal } \\
\text { communication }\end{array}$ \\
\hline
\end{tabular}

\section{Calculation of the water footprint}

Our approach to calculate the water consumption of a reservoir is based on Gleick [22] and Mekonnen and Hoekstra [46] by using gross water evaporation. Mekonnen and Hoekstra [46] calculate the water footprint of hydropower electricity $(W F)\left[\mathrm{m}^{3} / \mathrm{GJ}\right]$ by dividing the amount of water evaporated from the reservoir annually $(W E)$ [ $\mathrm{m}^{3} /$ year] by the amount of energy generated $(E G)[\mathrm{GJ} / \mathrm{yr}]$ :

$$
W F=\frac{W E}{E G}
$$

The total volume of evaporated water $(W E)\left[\mathrm{m}^{3} /\right.$ year $]$ from the hydropower reservoir over the year is calculated by:

$$
W E=A \times \sum_{t=1}^{365} E
$$

where $E$ is the daily evaporation [mm/day] and $A$ is the area of the reservoir $\left[\mathrm{km}^{2}\right]$.

\section{RESULTS}

The first map in Figure 1 shows all the existing hydroelectric plants in Brazil (as of end of 2016), including the ones that do not have a reservoir. It is evident that the plants are heavily concentrated in the Southeast, South and Midwest regions, with a few also existing in the Northeast and the North (Amazon region). The second map is showing the population density in Brazil as a reference point. 

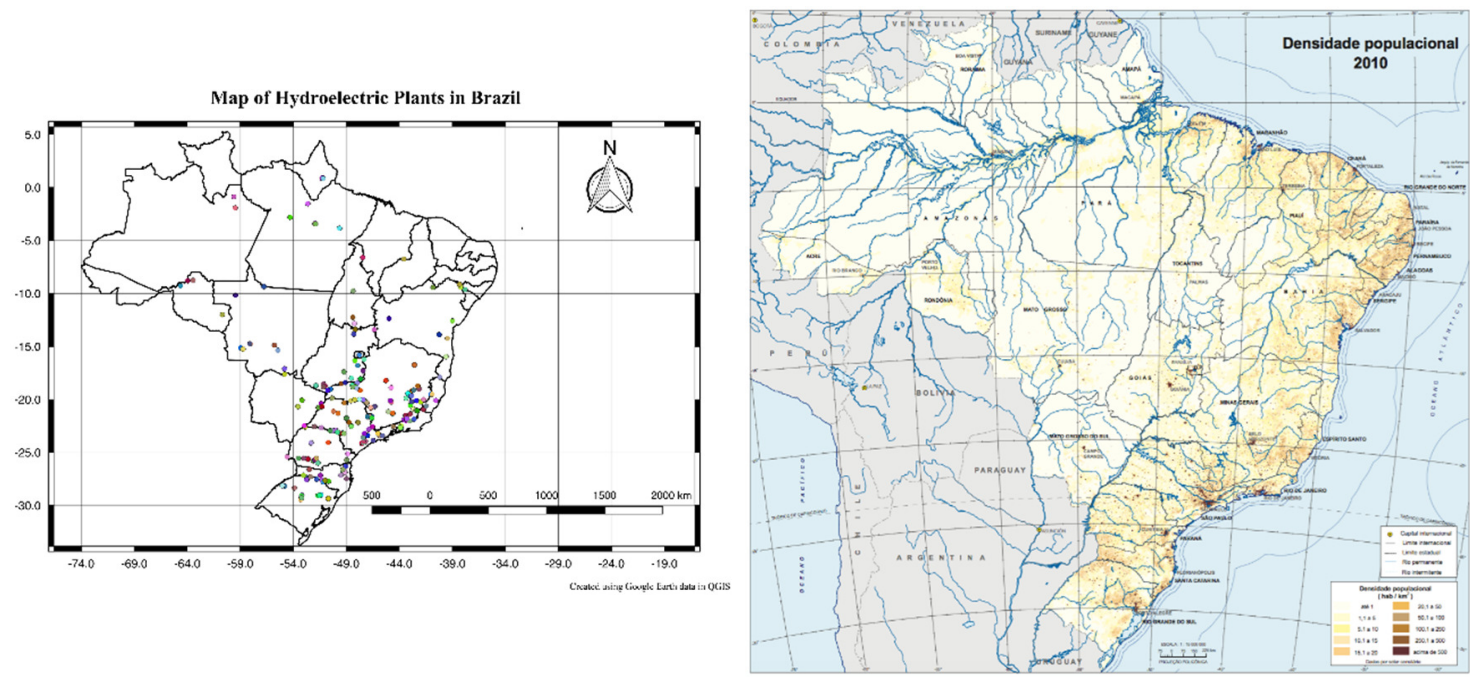

Figure 1. Maps of hydroelectric plants in Brazil in 2016 (own map), and density of population in 2010 [58]

Initially all 220 reservoirs used for hydroelectricity in Brazil, according to ANEEL, were considered. After analysing existing data and information for all reservoirs, we focused on 163 of them, taking out the ones that did not have a reservoir (run-of-the-river), those that had a very low electricity capacity and a small size reservoir $\left(1-2 \mathrm{~km}^{2}\right)$, and those that had no information on area, volume, and coordinates. The hydro plants/reservoirs that were not taken into account would not change the overall results by much, as they account for less than $20 \mathrm{~km}^{2}$ of area in total. Furthermore, some reservoirs belonged in more than one region. The percentages as to where these belong were taken from ANEEL and evaporation from each of those reservoirs belonging in more than one region was attributed percentagewise in each of those regions.

As is shown in Figure 2, evaporation does not change drastically through the years at first glance, although it is enough to show the impact of higher temperatures and drought periods. The Northeast is the region with the most evaporation. In the 7-year period, the Northeastern reservoirs never had an average evaporation less than $1,618 \mathrm{~mm}$ per year (in 2014), reaching the highest average in 2012 with $1,732 \mathrm{~mm}$ per year, when severe drought problems affected the region. The Midwest is the region with the second highest evaporation overall, with a minimum of $1,500 \mathrm{~mm}$ in 2011 , and a maximum of $1,590 \mathrm{~mm}$ in 2012. The North is third when it comes to average evaporation with a minimum of $1,412 \mathrm{~mm}$ in 2011, and a maximum of $1,486 \mathrm{~mm}$ in 2010. The Southeast is the region with the most reservoirs in the country (about 74), so its evaporation heavily affects the overall Brazilian results. Its minimum overall evaporation occurred in 2013 with $1,345 \mathrm{~mm}$, and its maximum in 2014 with $1,459 \mathrm{~mm}$, which was the highest in the 7-year analysis period, and also when the region suffered its worst drought in many years. The South is the region with the lowest overall average evaporation with a minimum of $1,133 \mathrm{~mm}$ in 2015 , and maximum $1,301 \mathrm{~mm}$ in 2012, when they had some drought issues as well. The Brazilian minimum evaporation was in 2013 with $1,377 \mathrm{~mm}$, and the maximum came in 2012 with $1,447 \mathrm{~mm}$.

Brazil has different kinds of climate since it has such a large area, which is also shown in Figure 3. The North has the most uniform evaporation with a minimum of $106 \mathrm{~mm}$ in February and a maximum of $142 \mathrm{~mm}$ in September. In contrast, the South is the one that has the most change through the seasons, with a minimum evaporation in June with $37 \mathrm{~mm}$ and a maximum in January with $158 \mathrm{~mm}$. The Northeast and the Midwest also have high minimums with 97 and $89 \mathrm{~mm}$ respectively in June and high maximums of 142 and $157 \mathrm{~mm}$ in September and October, respectively. The Southeast is the region with the second lowest evaporation overall and has a minimum of $63 \mathrm{~mm}$ in June and a maximum 
of $154 \mathrm{~mm}$ in December. The Southeast heavily affects the Brazilian overall values, which has a minimum of $69 \mathrm{~mm}$ in June and a maximum of $151 \mathrm{~mm}$ of evaporation in December.

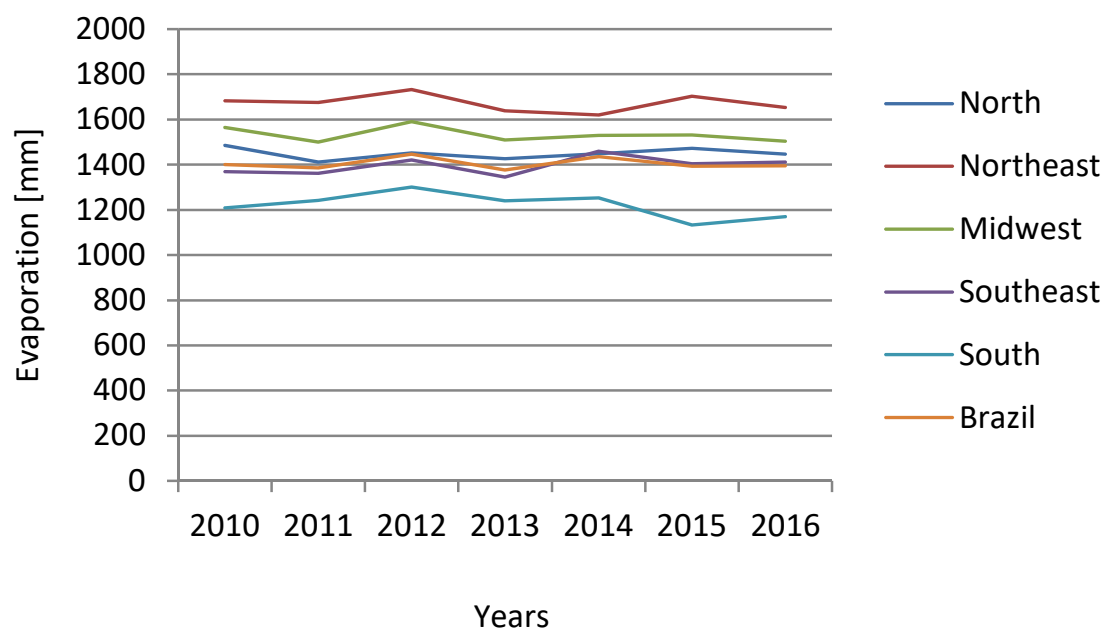

Figure 2. Average annual evaporation per region and country for the period 2010-2016

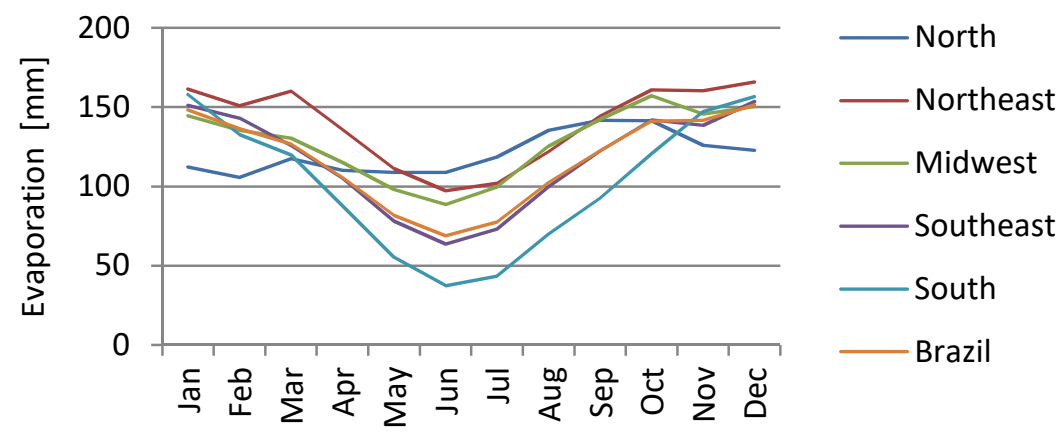

Months

Figure 3. Average monthly evaporation per region and country for the period 2010-2016

Table 3 shows the estimations of this study in comparison with results from ONS [10] for selected hydroelectric plants across the country. One important difference between this analysis and the one by ONS, apart from the different methods employed, is the difference data used for the calculation of evaporation. The ONS study estimated average monthly evaporation values based on average climate data for several locations for the years 1931 to 1990, from a limited number of meteorological stations. At present, through INMET, Brazil has a much better nationwide network of weather stations for collecting actual data from several places, in close proximity to reservoirs, which was not the case in 2004. Consequently, calculations of this sort have become more feasible and reliable than before. This study uses actual data from the past 7 years, from meteorological stations that are relatively new (most coming into operation in the period 2006-2010).

Some examples in Table 3 were chosen because they had the highest difference amongst all (e.g. Tucuruí and Lajeado), and some because they had almost the same results (e.g. Serra da Mesa, Luiz Gonzaga, and Três Marias). Although this is not a direct comparison, it nevertheless serves as an example that hints towards the dynamic nature of evaporation through time, making it thus clear that it should receive more attention and treated as such. 
Table 3. Comparison between estimations of this study (2010-2016) and ONS [10]

\begin{tabular}{ccccc}
\hline Hydroelectric power plant & State & Region & $\begin{array}{c}\text { ONS - Average } \\
\text { evaporation [mm/year] } \\
1931-1990\end{array}$ & $\begin{array}{c}\text { This study - Average } \\
\text { evaporation [mm/year] } \\
\text { 2010-2016 }\end{array}$ \\
\hline Tucuruí I e II & PA & North & 1,652 & 1,319 \\
Luís Eduardo Magalhães (Lajeado) & TO & North & 1,751 & 1,475 \\
Luiz Gonzaga (Itaparica) & BA & Northeast & 1,862 & 1,878 \\
Sobradinho & PE & Northeast & 1,909 & 1,795 \\
Emborcação & GO & Midwest & 1,556 & 1,445 \\
Serra da Mesa & GO & Midwest & 1,660 & 1,660 \\
TrêsIrmãos & MS & Midwest & 1,577 & 1,429 \\
Três Marias & MG & Southeast & 1,526 & 1,511 \\
ÁguaVermelha & SP & Southeast & 1,579 & 1,580 \\
Marimbondo & SP & Southeast & 1,536 & 1,446 \\
Itaipu & PR & South & 1,305 & 1,400 \\
Porto Primavera (Eng Sérgio Motta) & PR & South & 1,461 & 1,385 \\
\hline
\end{tabular}

Table 4 shows some extreme and some average examples of water footprints of hydroelectric power plants. Installed capacity was used for the calculations, so the water footprint showed is the minimum possible, since power plants rarely deliver their full potential. The less electricity these plants produce per year, the higher their water footprint will be. The most extreme example of water footprint is that of the Balbinapower plant with 2,613.79 $\mathrm{m}^{3} / \mathrm{MWh}$. Balbina is the largest reservoir in Brazil with an area of $4,437.72 \mathrm{~km}^{2}$ and the installed capacity of the plant is relatively small, $250 \mathrm{MW}$. The evaporation from such a reservoir is just shy of $6 \mathrm{~km}^{3}$ per year, so the water footprint is extremely large. Sobradinho and Porto Primavera also have very large reservoirs, but because of their installed capacity, their water footprint is not as big. On the other hand, power plants like Xingó and Ilha dos Pombos have a relatively high installed capacity and a relatively small reservoir, so their water footprints are very small. ÁguaVermelha and Emborcação belong somewhere in the average. The overall average water footprint for all 163 power plants is $103.7 \mathrm{~m}^{3} / \mathrm{MWh}$, but Balbina and a few more power plants singlehandedly raise the average significantly. Without considering the top 8 water footprints (Balbina, Batalha, Curuá-Una, Jurumirim, Pedra, Samuel, Sobradinho, and Três Marias) that have a minimum water footprint of $472.03 \mathrm{~m}^{3} / \mathrm{MWh}$, the average drops to $65.08 \mathrm{~m}^{3} / \mathrm{MWh}$, which is very close to the value $\left(68.14 \mathrm{~m}^{3} / \mathrm{MWh}\right)$ found by Torcellini et al. [17].

Table 4. Water footprint of selected hydroelectric power plants

\begin{tabular}{ccccc}
\hline Power plant & $\begin{array}{c}\text { Reservoir area } \\
{\left[\mathrm{km}^{2}\right]}\end{array}$ & $\begin{array}{c}\text { Installed capacity } \\
{[\mathrm{MW}]}\end{array}$ & $\begin{array}{c}\text { Evaporation } \\
{[\mathrm{mm} / \text { year }]}\end{array}$ & $\begin{array}{c}\text { Water footprint } \\
{\left[\mathrm{m}^{3} / \mathrm{MWh}\right]}\end{array}$ \\
\hline ÁguaVermelha & 673.63 & $1,396.2$ & $1,579.8$ & 87.01 \\
(Antiga José Ermírio de Moraes) & $1,049.56$ & 7,000 & $1,399.56$ & 23.96 \\
Itaipu & $2,976.98$ & 1,540 & $1,384.83$ & 305.6 \\
Porto Primavera & 485.08 & 1,192 & $1,444.59$ & 67.19 \\
(Eng ${ }^{\circ}$ Sérgio Motta) & $4,437.72$ & 250 & $1,289.89$ & $2,613.79$ \\
Emborcação & 25.3 & 90 & $1,607.93$ & 51.6 \\
Balbina & 6.21 & 130 & $1,185.05$ & 6.46 \\
Barra dos Coqueiros & 3.71 & 187 & $1,472.22$ & 3.33 \\
Castro Alves & $4,380.79$ & $1,050.3$ & $1,795.31$ & 854.82 \\
Ilha dos Pombos & 58.94 & 3,162 & $1,789.99$ & 3.81 \\
Sobradinho & & &
\end{tabular}




\section{DISCUSSION}

There is a concentration of hydropower plants/reservoirs in the Southeast and South of Brazil, which by definition can cause problems in case of a drought in these regions, especially since most of the population of the country is concentrated in the Southeast. The Northeast on the other hand, does not have a lot of hydroelectricity, but the hydropower plants they have are heavily susceptible to droughts. Careful planning of future energy capacity and also management of the existing hydroelectricity capacity are in order, so that vulnerability of the whole electricity system can be preserved.

It is vital to know how much water gets consumed because of the production of hydroelectricity, and therefore it is important to be able to calculate evaporation from the reservoirs in the country. To be able to do that, it is important to have good estimates of the reservoir areas through time, which might be the biggest problem in the calculation of evaporation at the moment. Such data does not currently exist, so a fixed reservoir area was used in this study, which is the maximum area possible, since this is the one usually reported in official documents. This has implications in the final results of evaporation presented, by overestimating values.

Furthermore, meteorological stations near the reservoirs are important to get the actual conditions in the area at any given point in time. The past 10 years, there has been a large number of new meteorological stations installed in the country, yet there is scope for more to be installed. Also, some data is missing (sometimes months at a time), so it would be of use to keep the existing meteorological stations in as good a condition as possible. In this study, the missing meteorological data was replaced by averages of the given days/months from the equivalent days/months in the rest of the 7-year period, which is similar to what Mekonnen and Hoekstra [46] did in their study. It was attempted to use data from nearby stations to compensate for the missing data at the weather stations used, but either these nearby stations were too far away (sometimes hundreds of kilometres), or they too had missing data for the same periods of time. In order to alleviate this problem and improve on the Mekonnen and Hoekstra [46] method, a somewhat different route was taken. After the data was checked for inconsistencies and possible negative or zero values as part of the quality control, the weighted arithmetic mean method was used. This way, the variations at specific times of the year were accounted for, making the data represent reality better than before. Although this part of the analysis could be improved with the provision of better data, the gaps were filled to a satisfactory degree in order to allow for some valuable estimations of evaporation in all reservoirs of the country.

The only study found in literature that estimates evaporation rates of reservoirs for the whole of Brazil is that of ONS [10]. The results of the present study are closely related to the results by ONS, although in some instances, there is a difference, which is attributed to the different method used and also the different weather data inputs. Although the ONS study is very valuable, evaporation is a dynamic process and it needs to be treated as such. It is important to estimate evaporation for every given year, since climatic conditions could change the amount of water lost significantly. To avoid problems in times of low water availability, it is important to anticipate when and where the problems will occur, and having the evaporation estimates is the first step in doing so, since it is vital to have these estimates for the sake of a water budget analysis.

The results presented above show the difference of evaporation through the seasons, which is mostly obvious in the Southeast and South of the country, where most of the reservoirs are concentrated. This knowledge could help in taking advantage of opportunities, like for example storing water in times of little evaporation and using it in times of high evaporation. Taking into account that the amount of water evaporated each year from these 163 reservoirs analysed in this study is a little over $60 \mathrm{~km}^{3}$ of water shows how important better management is. Surely, it can be argued that evaporation 
cannot be stopped, but most of it would not take place if it weren't for the hydroelectric reservoirs, therefore trying to save as much of this $60 \mathrm{~km}^{3}$ of water seems of great value.

Another interesting aspect of this analysis is the water footprint estimations. They can vary from as little as 0.1 to as much as $2,613.8 \mathrm{~m}^{3} / \mathrm{MWh}$. It could be argued that no valuable conclusions could come from such wide-ranging estimates. Nevertheless, this wide difference and extremes do actually provide a valuable metric. It becomes apparent that the less the installed capacity of a power plant is in relation to an increased reservoir area, the larger the water footprint is going to be. The vast majority of reservoirs in Brazil are listed as being solely used for the production of hydroelectricity. But, if the installed capacity of a given power plant is small and the reservoir holds a lot of water, it does not make sense to use the water solely for the production of electricity, therefore the water should also be used for other purposes. Depending on the area where the reservoir is located, a number of solutions could be applicable. For example, energy storage through uprating of older dams with additional generators could increase their peak power output capacity, thereby increasing its capacity to act as a virtual grid energy storage unit. In addition, thanks to the development of the electric vehicle, electrochemical grid storage is possible at a lower price than in the past, especially since batteries for stationary storage do not suffer from mass or volume constraints, although this solution depends a lot on whether the battery storage efficiency is high enough to justify storage of energy in a different way than reservoir storage. Also, excess water could irrigate sugarcane crops and be used in the production process of biofuels if facilities exist nearby. Furthermore, although such solutions are possible for the existing reservoirs, planning future hydroelectric plants should be done having their future water footprint in mind, so that as little water as possible is lost.

In this study, the water footprint per reservoir was calculated by using the total evaporation from the reservoir. One could argue though that before the creation of a given reservoir, a river was flowing through this area (although the evaporation from the river would be insignificant compared to the evaporation from the reservoir), and also evapotranspiration from land and vegetation would take place. However, as noted in Mekonnen and Hoekstra [46], the water footprint is not meant to refer to additional evaporation compared to a reference situation, rather quantifying the volume of water consumption that can be associated with a specific human purpose. Taking this into account, it is logical to consider the full reservoir evaporation for the purpose of the reservoir (electricity production in this case).

It needs to be noted that seepage losses are not considered water consumption, since the water can become available downstream or recharge ground water resources as suggested by Gleick [16], and Healy et al. [19]. Also, water being used during the construction of the dam, but also decommissioning is not taken into account, since this study is only about the operation of the hydropower plants. Finally, it is recognised that reservoirs and consequently hydroelectricity, can have many direct and indirect effects, like inundation of agricultural land, impairing of fish migration, loss of terrestrial vegetation and fauna, interference in sediment transport, loss of cultural/historical heritage, relocation of populations, etc. However, this work was not done in regards to ecological impacts or the human value of the reservoirs, but merely providing a method for evaluating the water evaporated off the reservoirs as a function of energy produced.

\section{CONCLUSION}

This paper offers an understanding and estimation of the water consumption of hydroelectricity in Brazil. The recent droughts in the country, but also the rise of interest towards the water-energy nexus have given the opportunity for a new perspective towards dealing with problems of availability and security of water and energy. For understanding and evaluating the water-energy nexus, it is firstly important to 
estimate evaporation from the reservoirs in Brazil. This study used a modified Penman-Monteith equation to estimate evaporation from hydroelectric reservoirs for the whole country, and subsequently used this information to also estimate the water footprint of hydroelectric power stations for the whole country as well, for the period 2010-2016. The results showed that evaporation rose in 2012 in the Northeast due to a drought in the region, and also in the Southeast during 2014. Additionally, the results show the great difference of evaporation throughout the year by region. By knowing how much water is lost (about $60 \mathrm{~km}^{3}$ per year in the country) in space and time, it is possible to use the information for a water budget analysis of each area, and to have an idea as to which areas are in more immediate danger of availability of resources. Also, water footprint results show within their wide range of results $\left(0.1\right.$ to $\left.2,613.8 \mathrm{~m}^{3} / \mathrm{MWh}\right)$, that there are great opportunities to start managing water much more prudently, and also offer an opportunity to think carefully about future planning of the energy sector.

\section{REFERENCES}

1. Bellfield, H., Water, Energy and Food Security Nexus in Latin America and the Caribbean, Report, Global Canopy Programme, 2015, https://www.gov.uk/dfid-research-outputs/water-energy-and-food-security-nexus-in -latin-america-and-the-caribbean, [Accessed: 11-June-2018]

2. Ministry of Mines and Energy, 2024 Brazilian Energy Expansion Plan - PDE 2024, 2016.

3. de Faria, F. A. M., Jaramillo, P., Sawakuchi, H. O., Richey, J. E. and Barros, N., Estimating Greenhouse Gas emissions from future Amazonian Hydroelectric Reservoirs, Environ. Res. Lett., Vol. 10, No. 12, 124019, 2015, https://doi.org/10.1088/1748-9326/10/12/124019

4. Cooley, H., Fulton, J. and Gleick, P. H., Water for Energy: Future Water needs for Electricity in the Intermountain West, Pacific Institute, Oakland, USA, 2011, https://pacinst.org/wp-content/uploads/2013/02/water_for_energy.pdf, [Accessed: 11-June-2018]

5. International Energy Agency, Water for Energy (excerpt from the World Energy Outlook 2012), Paris, France, 2012, https://www.iea.org/publications/freepublications/publication/English.pdf, [Accessed: 11-June-2018]

6. Rodriguez, D. J., Delgado, A., DeLaquil, P. and Sohns, A., Thirsty Energy, Water Papers, World Bank, Washington D. C., USA, 2013, https://openknowledge.worldbank.org/handle/10986/16536, [Accessed: 11-June-2018]

7. Intergovernmental Panel on Climate Change, Special Report on Renewable Energy Sources and Climate change mitigation: Summary for Policymakers and Technical Summary, 2012, https://www.ipcc.ch/pdf/special-reports/srren/ SRREN_FD_SPM_final.pdf, [Accessed: 11-June-2018]

8. Macknick, J., Newmark, R., Heath, G. and Hallett, K. C., Operational Water consumption and withdrawal Factors for Electricity generating Technologies: A review of existing Literature, Environ. Res. Lett., Vol. 7, No. 4, 045802, 2012, https://doi.org/10.1088/1748-9326/7/4/045802

9. National Water Agency, Water Resources in Brazil: 2013 (in Brazilian), 2013.

10. National Electricity System Operator, Net Evaporation in Hydroelectric Power Plants (in Brazilian), 2004.

11. Bueno, E. O., de Mello, C. R. and Alves, G. J., Evaporation from Camargos Hydropower Plant Reservoir: Water Footprint characterization, Brazilian Journal of Water Resources, Vol. 21, No. 3, pp 570-575, 2016, https://doi.org/10.1590/2318-0331.011616021 
12. Fischmann, F. and Chaffe, P. L. B., The Water Footprint of Hydroelectricity in Santa Catarina State - Southern Brazil, $7^{\text {th }}$ International Conference on Water Resources and Environment Research, June 5-9, Kyoto, Japan, 2016.

13. United Nations World Water Assessment Programme, The United Nations World Water Development Report 2014: Water and Energy, UNESCO, Paris, France, 2014.

14. Fthenakis, V. and Kim, H. C., Life-cycle uses of Water in U.S. Electricity generation, Renewable and Sustainable Energy Reviews, Vol. 14, No. 7, pp 2039-2048, 2010, https://doi.org/10.1016/j.rser.2010.03.008

15. Gerbens-Leenes, W., Hoekstra, A. Y. and Van der Meer, T. H., The Water Footprint of Energy from Biomass: A quantitative assessment and consequences of an increasing share of Bio-energy in Energy Supply, Ecological Economics, Vol. 68, No. 4, pp 1052-1060, 2009, https://doi.org/10.1016/j.ecolecon.2008.07.013

16. Gleick, P. H., Water and Energy, Annu. Rev. Energy Environ., Vol. 19, pp 267-299, 1994, https://doi.org/10.1146/annurev.eg.19.110194.001411

17. Torcellini, P., Long, N. and Judkoff, R., Consumptive Water use for U.S. Power production, National Renewable Energy Laboratory, NREL/TP-550-33905, 2003, www.nrel.gov/docs/fy04osti/33905.pdf, [Accessed: 15-April-2017]

18. Dodder, R. S., A review of Water use in the U.S. Electric Power Sector: Insights from Systems-level Perspectives, Current Opinion in Chemical Engineering, Vol. 5, pp 7-14, 2014, https://doi.org/10.1016/j.coche.2014.03.004

19. Healy, R. W., Alley, W. M., Engle, M. A., McMahon, P. B. and Bales, J. D., The Water-energy Nexus - An Earth Science Perspective, U.S. Geological Survey Circular, 1407, 107 p, https://doi.org/10.3133/cir1407

20. Siddiqi, A. and Anadon, L. D., The Water-energy Nexus in Middle East and North Africa, Energy Policy, Vol. 39, No. 8, pp 4529-4540, 2011, https://doi.org/10.1016/j.enpol.2011.04.023

21. Bakken, T. H., Killingtveit, A., Engeland, K., Alfredsen, K. and Harby A., Water consumption from Hydropower Plants - Review of published estimates and assessment of the Concept, Hydrologic and Earth Systems Science, Vol. 17, pp 3983-4000, 2013, https://doi.org/10.5194/hess-17-3983-2013

22. Gleick, P. H., Environmental Consequences of Hydroelectric development: The Role of Facility Size and Type, Energy, Vol. 17, No. 8, pp 735-747, 1992, https://doi.org/10.1016/0360-5442(92)90116-H

23. Lehner, B., Liermann, C. R., Revenga, C., Vörösmarty, C., Fekete, B., Crouzet, P., Döll, P., Endejan, M., Frenken, K. and Magome, J., High-resolution mapping of the World's Reservoirs and Dams for sustainable River-flow management, Frontiers in Ecology and the Environment, Vol. 9, No. 9, pp 494-502, 2011, https://doi.org/10.1890/100125

24. AQUASTAT, Dams - $\quad$ Geo-referenced Database, http://www.fao.org/nr/water/aquastat/dams/index.stm, [Accessed: 15-April-2017]

25. Pasqualetti, M. J. and Kelley, S., Cost of Water and Energy in Arizona, Arizona Water Institute, Tempe, Arizona, USA, 2007, http://www.circleofblue.org/wp-content/uploads/2010/08/AZ-Solar-Water-Fact-She et.pdf, [Accessed: 11-June-2018]

26. Zhao, D. and Liu, J., A new approach to assessing the Water Footprint of Hydroelectric Power based on allocation of Water Footprints among Reservoir Ecosystem Services, Physics and Chemistry of the Earth, Vol. 79-82, pp 40-46, 2015, https://doi.org/10.1016/j.pce.2015.03.005

27. Maestre-Valero, J. F., Martínez-Granados, D., Martínez-Alvarez, V. and Calatrava, J., Socio-economic Impact of evaporation losses from Reservoirs under Past, current and future Water availability Scenarios in the Semi-arid Segura Basin, Water Resour. Manag., Vol. 27, No. 5, pp 1411-1426, 2013, https://doi.org/10.1007/s11269-012-0245-4 
28. Martinez-Granados, D., Maestre-Valero, J. F., Calatrava, J. and Martinez-Alvarez, V., The Economic impact of Water evaporation losses from Water Reservoirs in the Segura Basin, SE Spain, Water Resour. Manag., Vol. 25, No. 13, pp 3153-3175, 2011, https://doi.org/10.1007/s11269-011-9850-x

29. Gallego-Elvira, B., Martínez-Alvarez, V., Pittaway, P., Brink, G. and Martín-Gorriz, B., Impact of Micrometeorological Conditions on the efficiency of artificial Monolayers in reducing evaporation, Water Resour. Manag., Vol. 27, No. 7 , pp 2251-2266, 2013, https://doi.org/10.1007/s11269-013-0286-3

30. Finch, J. and Calver, A., Methods for the quantification of evaporation from Lakes, Prepared for the World Meteorological Organization's Commission for Hydrology, Wallingford, Oxfordshire, UK, 2008, http://nora.nerc.ac.uk/id/eprint/14359/ 1/wmoevap_271008.pdf, [Accessed: 11-June-2018]

31. US Geological Survey (USGS), Hydroelectric Power Water use, 2010, http://ga.water.usgs.gov/edu/wuhy.html, [Accessed: 04-November-2016]

32. Energy Information Administration, Washington D. C., USA, https://www.eia.gov, [Accessed: 15-April-2017]

33. Mielke, E., Diaz Anadon, L. and Narayanamurti, V., Water consumption of Energy Resource extraction, processing, and conversion, Energy Technology Innovation Policy Discussion Paper No. 2010- 15, Belfer Center for Science and International Affairs, Harvard Kennedy School, Harvard University, Cambridge, Massachusetts, USA, 2010.

34. Averyt, K., Fisher, J., Huber-Lee, A., Lewis, A., Macknick, J., Madden, N., Rogers, J. and Tellinghuisen, S., Freshwater use by U.S. Power Plants: Electricity's thirst for a precious Resource, A Report of the Energy and Water in a warming World initiative, Union of Concerned Scientists, Cambridge, Massachusetts, USA, 2011.

35. Meldrum, J., Nettles-Anderson, S., Heath, G. and Macknick, J., Life Cycle Water use for Electricity generation: A review and harmonization of Literature estimates, Environ. Res. Lett., Vol. 8, 015031, 18 p, 2013.

36. Kenny, J. F., Barber, N. L., Hutson, S. S., Linsey, K. S., Lovelace, J. K. and Maupin, M. A., Estimated use of Water in the United States in 2005, US Geol. Survey Circ., Circular 1344, 52 p, 2009.

37. Dziegielewski, B. and Bik, T., Water use Benchmarks for Thermoelectric Power Generation, Research Report of the Department of Geography and Environmental Resources, Southern Illinois University, Carbondale, Illinois, USA, 2006.

38. Yang, X. and Dziegielewski, B., Water use by Thermoelectric Power Plants in the United States, J. Am. Water Resources Assoc., Vol. 43, No. 1, pp 160-169, 2007, https://doi.org/10.1111/j.1752-1688.2007.00013.x

39. Rutberg, M., Delgado, A., Herzog, H. and Ghoniem, A., A System-level Generic Model of Water use at Power Plants and its Application to Regional Water use estimation, Proceedings of the ASME 2011 Int. Mechanical Engineering Congr. and Exposition, Denver, Colorado, USA, 2011, https://doi.org/10.1115/IMECE2011-63786

40. Carvalho, L. G., Evangelista, A. W. P., Oliveira, K. M. G., Silva, B. M., Alves, M. C., Sa Junior, A. and Miranda, W. L., FAO Penman-Monteith Equation for Reference evapotranspiration from missing Data, IDESIA, Vol. 31, No. 3, pp 39-47, 2013, https://doi.org/10.4067/S0718-34292013000300006

41. Mendonca, J. C., Esteves, B. S. and de Sousa, E. F., Reference evapotranspiration (ETo) in North Fluminense, Rio de Janeiro, Brazil: A review of Methodologies of the calibration for different Periods of analysis, 2013, https://www.intechopen.com/books/evapotranspiration-an-overview/reference-evap otranspiration-eto-in-north-fluminense-rio-de-janeiro-brazil-a-review-of-methodolo gies, [Accessed: 11-June-2018] 
42. da Cunha, F. F., da Silva, T. R., Ximenes, A. R. and Batista, R. O., Comparative Study of Methods for estimating evapotranspiration Reference in Paranaiba City, Brazil, Global Journal of Human-social Science: B Geography, Geo-sciences, Environmental Science \& Disaster Management, Vol. 15, No. 1, pp 17-25, 2015.

43. Majidi, M., Alizadeh, A., Farid, A. and Vazifedoust, M., Estimating evaporation from Lakes and Reservoirs under limited Data condition in a Semi-Arid Region, Water Resour. Manag., Vol. 29, No. 10, pp 3711-3733, 2015, https://doi.org/10.1007/s11269-015-1025-8

44. Morton, F. I., Operational estimates of Areal evapotranspiration and their significance to the Science and Practice of Hydrology, Journal of Hydrology, Vol. 66, No. 1-4, pp 1-76, 1983, https://doi.org/10.1016/0022-1694(83)90177-4

45. INMET, BDMEP, Meteorological Database for Teaching and Research (in Brazilian), 2016, http://www.inmet.gov.br/portal/index.php?r=bdmep/bdmep, [Accessed: 11-June-2018]

46. Mekonnen, M. M. and Hoekstra, A. Y., The blue Water Footprint of Electricity from Hydropower, Hydrol. Earth Syst. Sci., Vol. 16, No. 1, pp 179-187, 2012, https://doi.org/10.5194/hess-16-179-2012

47. Monteith, J. L., Weather and Water in the Sudano-Sahelian Zone, Soil Water Balance in the Sudano-Sahelian Zone, Proceedings of the Niamey Workshop, International Association of Hydrological Sciences Publication, pp 11-28, Niamey, Niger, 18-23 February, 1991.

48. Shuttleworth, W. J., Evaporation (Chapter 4), Handbook of Hydrology, (Maidment, D. R., ed.), McGraw-Hill Inc., New York, USA, 1992.

49. McMahon, T. A., Peel, M. C., Lowe, L., Srikanthan, R. and McVicar, T. R., Estimating actual, potential, reference crop and pan evaporation using standard Meteorological Data: A pragmatic Synthesis, Hydrol. Earth Syst. Sci., Vol. 17, pp 1331-1363, 2013, https://doi.org/10.5194/hess-17-1331-2013

50. de Bruin, H. A. R. and Stricker, J. N. M., Evaporation of Grass under non-restricted Soil Moisture Conditions, Hydrol. Sci. J., Vol. 45, No. 3, pp 391-406, 2000, https://doi.org/10.1080/02626660009492337

51. Lenters, J. D., Kratz, T. K. and Bowser, C. J., Effects of Climate variability on Lake evaporation: Results from a long-term Energy Budget Study of Sparkling Lake, northern Wisconsin (USA), J. Hydrol., Vol. 308, No. 1-4, pp 168-195, 2005, https://doi.org/10.1016/j.jhydrol.2004.10.028

52. Rosenberry, D. O., Winter, T. C., Buso, D. C. and Likens, G. E., Comparison of 15 evaporation Methods applied to a small Mountain Lake in the northeastern USA, J. Hydrol., Vol. 340, No. 3-4, pp 149-166, 2007, https://doi.org/10.1016/j.jhydrol.2007.03.018

53. Stephen, B. K. T., Eng, B. S. and Lloyd, H. C. C., Modelling hourly and daily open-water evaporation Rates in areas with an Equatorial Climate, Hydrol. Process, Vol. 21, No. 4, pp 486-499, 2007, https://doi.org/10.1002/hyp.6251

54. Shakir, A., Narayan, C. G. and Ranvir, S., Evaluating best evaporation estimate Model for Water Surface evaporation in Semi-arid Region, India, Hydrol. Process, Vol. 22, No. 8, pp 1093-1106, 2008, https://doi.org/10.1002/hyp.6664

55. McJannet, D. L., Webster, I. T. and Cook, F. J., An Area-dependent Wind Function for estimating open Water evaporation using Land-based Meteorological Data, Environ. Model Softw., Vol. 31, pp 76-83, 2012, https://doi.org/10.1016/j.envsoft.2011.11.017

56. Monteith, J. L., Evaporation and the Environment, The State and Movement of Water in Living Organisms (Fogg, G. E., ed.), Cambridge University Press, London, UK, 1965.

57. McJannet, D. L., Webster, I. T., Stenson, M. P. and Sherman, B. S., Estimating open Water evaporation for the Murray Darling Basin, A Report to the Australian 
Government from the CSIRO Murray-Darling Basin Sustainable Yields Project, Commonwealth Scientific and Industrial Research Organisation, Canberra, Australia, 2008.

58. Brazilian Institute of Geography and Statistics, Atlas of the Demographic Census (in Brazilian), 2010.

Paper submitted: 27.02 .2018

Paper revised: 14.05 .2018

Paper accepted: 21.05.2018 